\title{
The education question in theory and the theory question in education-Introduction to the Special Issue
}

\author{
Julie Allan • Richard Edwards
}

Published online: 19 April 2012

(C) Springer Science+Business Media B.V. 2012

This special issue focuses on educational theory and arose from the First International Theorising Education Conference of the Laboratory for Educational Theory (http://www. theorylab.co.uk), held at the University of Stirling in July 2010. TheoryLab was established as a space for the exploration of the work of theory in educational research and educational practice. There is an emphasis on experimentation, engagement and capacity building and of practices of theorising as critique, intervention and reframing. The conference invited participants to consider the theory question in education and the education question in theory. The conference itself was a lively affair, with participants engaging in some more experimental forms of exchange, which were captured, by them and by us, as 'lines of flight' (Deleuze and Guattari 1987, p. 161).

The papers that comprise this special issue capture some of the spirit of experimentation and certainly offer some new lines of flight. Lisbeth Lundahl considers the concept of 'knowledge capital' and its two main educational effects. The first of these is the transformation of education to ensure it supports economic growth and competition and Lundahl notes the impact of this globally. The second effect concerns the increasing demand for scientific evidence for policy and practice, using narrowly defined methods and techniques and the negative consequences for educational research, and educational theory are underlined. Taking a rational argument perspective, Lundahl argues for greater dialogue among researchers, with the funders of research and with teachers and parents to challenge the current situtation and for a rethinking of the place of educational theory.

Christine Stephen looks for theory in pre-school education and finds much of it operating at an implicit level, with pre-school teachers speaking of practices which are informed by often contradictory and incompatible theories, but rarely able to make these explicit. This points to the embeddedness of much theory in education practices, but also that incommensurate theories are not inconsisent with such practices. Empirical and normative issues on how theory works in the day-to-day emerge for consideration. Stephen

\footnotetext{
J. Allan $(\bowtie) \cdot$ R. Edwards

School of Education, University of Stirling, Stirling, Scotland, UK

e-mail: j.e.allan@stir.ac.uk

R. Edwards

e-mail: r.g.edwards@stir.ac.uk
} 
sees the recent influence of poststructuralist theories as a force for good, but calls upon teacher educators to help pre-school teachers to engage more explicitly with theory.

Christiane Thompson offers the suggestion of one philosophical method that engages with the empirical. Relating Heidegger's philosophical endeavour to empirical materials, Thompson challenges the categorical make-up of our experience and the expectation that empirical research (merely) reconstructs pedagogical themes. Her althernative approach to educational research is one that reflects the educational-philosophical categories. She argues that this changes the world and our engagement within it.

In How theory matters: Formative assessment practices and their different relations to education, Barbara Crossouard and John Pryor consider formative assessment practices and theories and their relations to education. They explore the possibility of formative assessment becoming properly educational and offer a framework of formative assessment which recognises the educator's position, rather than it merely being an instrumental technique. This allows for an engagement in meaning-making which is dialogic and which takes account of politics and contingencies and seems to us to offer exciting possibilities.

Karsten Kenklies invites us to consider educational theory as topological logic. He draws on Schleiermacher and Herbart to explore, in a more fundamental way, the relationship between educational theory and practice. Kenklies provides some much needed engagement with what could be considered educational science. His paper points to theoretical traditions and framings which are relatively unfamiliar in the English-writing world, something that is significant in considering the universalist pretensions or aspirations of certain forms of theory in a world of difference.

Theory and texts of educational policy: Possibilities and constraints, by Teresa Gonçalves, Elisabete Gomes, Mariana Alves, Nair Azevedo and Cláudia Neves contains an 'intensive reading' of European policy texts on lifelong learning that, as they suggest, 'endorses alternative expectations' This is a reading 'with love' but also one that attends to power which, quoting from Rancière, they argue as being 'more interesting and fruitful today than the endless task of unmasking the fetishes and the ghost or the endless demonstration of the omnipotence of the beast' (p. 193).

Elisabete Xavier Gomez takes us to the Unbearable lightness of being, using cities as contexts with a worldly quality (Biesta 2010) for reshaping education. She presents an approach to children's education as a process of making room for newcomers, releasing possibilities of unexpected events, relationships and desires. This 'pedagogy of interruption' challenges the notion that education is institutional by creating an unbearable burden which is also light and which comes through the exposure to new educational activitiesand to new people-outside of school, for example in parks and museums.

Hamish Ross and Gregory Mannion take up Tim Ingold's (2000, 2011) notion of dwelling to explore how communication takes place with reference to the shared, dwelt in, environment and seek to reframe knowing within a dwelling ontology. Drawing on Ingold, they offer an 'education of attention', especially in relation to the environment and, by drawing on place, they open up the possibilities of politics within a curriculum that functions as a 'lived story'.

In Lurking, distilling, exceeding, vibrating, Lynn Fendler asks what theory has been doing in education, a question which she answers historically, and what theory might be doing, which she addresses imaginatively. In her historical analysis, she finds that theory has been lurking within educational research policies, practices and structures, distilling complex ideas and rendering them into language we can use, and reframing understanding on a more acceptable pedagogical basis. Fendler analyses a number of 'sticking points' in order to consider what is properly educational about educational theory. She then invokes 
the imaginary, enjoining us to engage with theory in ways that enable it to exceed, generate and vibrate. These exciting propositions enable us to rethink education-and theory's place in it-as a more dynamic and experimental beast. This invocation of the imaginary points also to the emotional and non-rational in the work of theory.

This volume provides some stimulating critical commentary on the educational function of theory-and of the theoretical dimensions of education-as well as creative and imaginative thoughts about what particular theory and theorising does and might be enabled to do. The suggestions about new directions for theory in education place new obligations on educators, not just to engage differently with theory, but to practice theorising in order to engage differently with education-and with those in it. We have previously identified a lack of capacity in relation to theory (Biesta et al. 2011) and some resistance to engaging with theory within education (Allan 2008). We have also underlined the need for a greater understanding of "how theory 'works', what it makes possible and also what it makes difficult or even impossible" (Biesta et al. 2011, p 234). The papers in this volume represent a contribution in this regard.

\section{References}

Allan, J. (2008). Rethinking inclusive education: The philosophers of difference in practice. Dordrecht: Springer.

Biesta, G. J. J. (2010). Good education in an age of measurement: Ethics, politics, democracy. Boulder, CO: Paradigm.

Biesta, G. J. J., Allan, J., \& Edwards, R. G. (2011). The theory question in research capacity building in education: Towards an agenda for research and practice. British Journal of Educational Studies, 59(3), 225-239.

Deleuze, G., \& Guattari, F. (1987). A thousand plateaus: Capitalism and schizophrenia. London: The Athlone Press.

Ingold, T. (2000). The perception of the environment: essays on livelihood, dwelling and skill. London: Routledge.

Ingold, T. (2011). Being alive. Essays on movement, knowledge and description. London: Routledge. 